\title{
Profil Klinis dan Faktor Risiko Hidrosefalus Komunikans dan Non Komunikans pada Anak di RSUD dr. Soetomo
}

Denisa Dwi Rahmayani, Prastiya Indra Gunawan, ${ }^{*}$ Budi Utomo ${ }^{* *}$

* Departemen Ilmu Kesehatan Anak, RSUD Dr. Soetomo Surabaya

** Departemen Ilmu Kesehatan Masyarakat, Fakultas Kedokteran Unversitas Airlangga Surabaya

Latar belakang. Hidrosefalus merupakan salah satu kelainan kongenital tersering pada anak yang dapat menyebabkan penurunan kualitas hidup anak. Penyebab hidrosefalus masih belum banyak diketahui dan faktor risikonya belum banyak dipelajari.

Tujuan. Mengevaluasi dan mengidentifikasi faktor risiko yang berhubungan dengan terjadinya hidrosefalus komunikans dan non komunikans pada anak.

Metode. Penelitian analitik observasional pada 80 pasien anak yang menderita hidrosefalus dengan menggunakan data sekunder di pusat rekam medis RSUD dr. Soetomo. Analisis menggunakan chi-square dan regresi logistik.

Hasil. Prevalensi hidrosefalus komunikans dan non komunikans adalah 41,25\% dan 58,75\%. Hasil analisis menunjukkan meningoensefalitis memiliki hubungan dengan hidrosefalus komunikans ( $\mathrm{p}=0,023)$. Data statistik menunjukkan bahwa manifestasi klinis terbanyak pada hidrosefalus adalah edema otak.

Kesimpulan. Meningoensefalitis merupakan faktor risiko hidrosefalus komunikans. Sari Pediatri 2017;19(1):25-31

Kata kunci: anak, hidrosefalus komunikans, non komunikans, meningoensefalitis

\section{Clinical Profile and Risk Factors of Pediatric Communicating and Non Communicating Hydrocephalus at RSUD dr. Soetomo}

Denisa Dwi Rahmayani, Prastiya Indra Gunawan, ${ }^{*}$ Budi Utomo ${ }^{* *}$

Background. Hydrocephalus is one of the most common congenital disease in children leading to decrease quality of life. The cause of hydrocephalus is still poorly understood and its risk factors have not been much studied.

Objective. To evaluate and identify the risk factors associated with pediatric communicating and non communicating hydrocephalus. Method. An analitic observational study, that was conducted in 80 pediatric patient who suffer hydrocephalus using secondary data at center of medical records in RSUD dr. Soetomo. Analysis using Chi-squre and binary logistic regression.

Result. Prevalence of communicating hydrocephalus is $41,25 \%$ and prevalence of non-communicating hydrocephalus is $58,75 \%$. The result showed that meningoencephalitis has correlation to communicating hydrocephalus(sig=0.023). Statistic data showed the most clinical manifestation of hydrocephalus is brain edema.

Conclusion. Meningoencephalitis is a risk factor of communicating hydrocephalus. Sari Pediatri 2017;19(1):25-31

Keywords: pediatric, communicating hydrocephalus, non communicating hydrocephalus, meningoencephalitis

Alamat korespondensi: Dr. Denisa Dwi Rahmayani, Fakultas Kedokteran Universitas Airlangga, Jl. Mayjend Prof. Dr. Moestopo 47 Surabaya.

E-mail: denisadwirahmayani@gmail.com 
$\mathrm{H}$ idrosefalus merupakan salah satu kelainan kongenital yang paling sering terjadi pada anak. ${ }^{1}$ Kasus hidrosefalus bervariasi antara $0,8-3$ per 1000 kelahiran. ${ }^{1-3} \mathrm{Di}$ Indonesia, insiden hidrosefalus mencapai 10 permil. ${ }^{4}$ Hidrosefalus dapat menyebabkan konsekuensi yang serius pada anak meliputi penurunan kapasitas intelektual, defisit motorik, kesulitan perilaku sehingga memengaruhi kualitas hidup anak yang terbawa hingga dewasa. ${ }^{5}$ Penyebab hidrosefalus dapat terjadi pada masa prenatal dan perinatal, tetapi hal-hal apa saja yang memicu terjadinya kelainan tersebut sebagian besar belum diketahui secara pasti. ${ }^{7}$ Pemicu hidrosefalus tersering adalah perdarahan diikuti neoplasma dan infeksi meningitis. ${ }^{3}$ Hidrosefalus dibedakan menjadi hidrosefalus komunikans dan non komunikans/ obstruktif berdasarkan lokasi obstruksinya dan memiliki penanganan yang berbeda. ${ }^{1,6}$ Hingga saat ini belum ada penelitian mengenai faktor risiko hidrosefalus komunikans dan non komunikans.

Penelitian ini bertujuan untuk mengevaluasi dan mengidentifikasi faktor risiko yang berhubungan dengan terjadinya hidrosefalus komunikans dan non komunikans pada anak. Hal ini diperlukan untuk mengurangi insidens hidrosefalus komunikans dan non komunikans pada anak dan melakukan penanganan yang tepat bagi penderita.

\section{Metode}

Penelitian analitik observasional dengan teknik pengambilan data menggunakan total sampling yang dilakukan di pusat rekam medis RSUD dr. Soetomo. Data yang digunakan adalah data pasien rawat inap SMF Ilmu Kesehatan Anak periode Januari 2014Januari 2016. Ditemukan 92 data pasien hidrosefalus anak dengan 80 yang memenuhi kriteria inklusi dan eksklusi.

Kriteria inklusi adalah pasien berusia 0-12 tahun yang memiliki salah satu atau lebih faktor hidrosefalus, antara lain, hidrosefalus kongenital, umur, jenis kelamin, prematuritas, asfiksia, perdarahan otak, post infeksi meningitis, infeksi CMV, ensefalitis, tuberkulosis, meningoensefalitis, edema otak, leukemia limfoblastik akut, pneumonia, abses otak, kista otak, mielokel dan otitis media kronis. Sampel kasus merupakan pasien dengan diagnosis hidrosefalus komunikans, sedangkan sampel kontrol adalah pasien dengan diagnosis hidrosefalus non-komunikans. Kriteria eksklusi adalah usia lebih dari 12 tahun, memiliki diagnosis hidrosefalus tipe isolated, multilobulated atau unidentified dan memiliki data rekam medis yang tidak lengkap.

Pengukuran variabel hidrosefalus komunikans atau non komunikans dilihat dari diagnosis dokter atau hasil CT-scan pada rekam medis (skala nominal). Usia pada penelitian ini dibagi menjadi empat kategori menurut WHO, yaitu neonate (0-30 hari), infant (1 bulan-2 tahun), young child (2-6 tahun), dan child (6-12 tahun) (skala ordinal). Jenis kelamin dibagi menjadi laki-laki atau perempuan (skala nominal).

Analisis data digunakan SPSS 23. Karakteristik subyek dan manifestasi klinis hidrosefalus disajikan dalam bentuk tabel dan narasi. Uji chi-square dilakukan untuk melihat hubungan antara variabel faktor hidrosefalus dengan tipe hidrosefalus. Uji Fisher dilakukan bila uji chi-square tidak memenuhi syarat. Analisis regresi logistik digunakan untuk melihat variabel bebas yang paling bermakna dari variabel bebas lain yang diteliti, setelah itu nilai probabilitas dapat ditentukan.

\section{Hasil}

Jumlah total pasien hidrosefalus komunikans adalah 33 orang dari $80(41,25 \%)$ pasien hidrosefalus total, sedangkan pasien hidrosefalus non komunikans berjumlah 47 orang $(58,75 \%)$. Duabelas pasien dieksklusi sehingga didapatkan jumlah sampel total 80 orang.

Tabel 1 menunjukkan jumlah pasien hidrosefalus lebih banyak berjenis kelamin laki-laki (67,5\%). Kategori infant merupakan kelompok umur terbanyak 37 (46,25\%) orang, sedangkan jumlah pasien paling sedikit pada kategori neonate 4 (5\%). Subyek penelitian banyak berasal dari luar Surabaya $(72,5 \%)$ dengan 43 kasus rujukan $(53,75 \%)$. Sebagian besar pasien memiliki status gizi baik, $17,5 \%$ dengan gizi kurang, dan $7,5 \%$ dengan gizi buruk.

Tabel 2 menunjukkan $18(22,5 \%)$ orang memiliki manifestasi klinis terbanyak, yaitu edema otak, pneumonia $13(16,25 \%)$ dan meningoensefalitis 12 (15\%).

Hasil analisis bivariat menggunakan uji Fisher karena syarat uji chi-square tidak terpenuhi. Hasil analisis bivariat menunjukkan bahwa terdapat hubungan yang 
Denisa Dwi Rahmayani dkk: Profil klinis dan faktor risiko hidrosefalus komunikans dan non komunikans

Tabel 1. Karakteristik subyek

\begin{tabular}{lcc}
\hline & Komunikans & Non komunikans \\
\hline Jenis kelamin (\%) & & \\
Laki-laki & $20(25)$ & $34(42,5)$ \\
Perempuan & $13(16,25)$ & $13(16,25)$ \\
Usia (\%) & $1(1,25)$ & \\
Neonate (0-30 hari) & $12(15)$ & $3(3,75)$ \\
Infant $(1$ bulan-2 tahun) & $13(16,5)$ & $25(31,25)$ \\
Yong child (2-6 tahun) & $7(8,75)$ & $10(12,5)$ \\
Child (6-12 tahun) & & $9(11,25)$ \\
Asal (\%) & $10(12,5)$ & \\
Surabaya & $23(28,75)$ & $12(15)$ \\
Luar Surabaya & & $35(43,75)$ \\
Status gizi (\%) & \\
Baik & $26(32,5)$ & $34(42,5)$ \\
Kurang & $6(7,5)$ & $8(10)$ \\
Buruk & $1(1,25)$ & $5(6,25)$ \\
Kasus rujukan & $19(23,75)$ & $24(30)$ \\
\hline
\end{tabular}

Tabel 2. Manifestasi klinis hidrosefalus komunikans dan non komunikans

\begin{tabular}{lcccc}
\hline \multirow{2}{*}{ Faktor yang diteliti } & \multicolumn{4}{c}{ Jumlah kasus hidrosefalus } \\
\cline { 2 - 5 } & \multicolumn{3}{c}{ Komunikans } & \multicolumn{2}{c}{ Non komunikans } \\
\cline { 2 - 5 } & $\mathrm{n}$ & $\%$ & $\mathrm{n}$ & $\%$ \\
\hline Kongenital & 4 & 5 & 7 & 8,75 \\
Tumor otak & 4 & 5 & 6 & 7,5 \\
Asfiksia & - & 0 & 4 & 5 \\
Prematur & 2 & 2,5 & 6 & 7,5 \\
Perdarahan & 4 & 5 & 4 & 5 \\
CMV & - & 0 & 3 & 3,75 \\
Meningitis & 1 & 1,25 & 1 & 1,25 \\
Ensefalitis & 5 & 6,25 & 4 & 5 \\
TB & 4 & 5 & 6 & 7,5 \\
Meningoensefalitis & 9 & 11,25 & 3 & 3,75 \\
Edema otak & 7 & 8,75 & 11 & 13,75 \\
Leukimia limfoblastik akut & 3 & 3,75 & 1 & 1,25 \\
Pneumonia & 7 & 8,75 & 6 & 7,5 \\
Abses otak & - & 0 & 2 & 2,5 \\
Kista & 1 & 1,25 & 3 & 3,75 \\
Mielokel & 2 & 2,5 & 6 & 7,5 \\
OMK & 1 & 1,25 & - & 0 \\
\hline
\end{tabular}

signifikan antara meningoensefalitis dengan tipe hidrosefalus $(\mathrm{p}=0,023)$ dengan OR 5,5. Variabel lain memiliki nilai $\mathrm{p}>0,05$, hal ini menunjukkan bahwa tidak ada hubungan antara kejadian hidrosefalus komunikans dan non komunikans dengan 18 variabel lain yang diteliti.
Pada analisis multivariat dengan regresi logistik (Tabel 4) didapatkan nilai $\mathrm{p}=0,017$ yang berarti bahwa meningoensefalitis merupakan variabel yang paling berhubungan secara bermakna dengan kejadian hidrosefalus komunikans dibandingkan variabel lain yang diteliti. Pasien hidrosefalus yang mengalami 
Tabel 3. Hasil analisis bivariat

\begin{tabular}{|c|c|c|c|c|c|c|c|}
\hline & & Kon & kans & Non & hikans & & variat* \\
\hline & & $\mathrm{N}$ & $\%$ & $\mathrm{n}$ & $\%$ & $\mathrm{p}$ & $\begin{array}{c}\text { OR } \\
\text { (IK95\%) }\end{array}$ \\
\hline Jenis kelamin & Laki-Laki & 20 & 37 & 34 & 63 & 0,27 & $0,59(0,29-1,52)$ \\
\hline & Perempuan & 13 & 50 & 13 & 50 & & \\
\hline Usia & Neonatus & 1 & 25 & 3 & 75 & 0,275 & \\
\hline & Bayi & 12 & 32 & 25 & 68 & & \\
\hline & Anak muda & 13 & 57 & 10 & 43 & & \\
\hline & Anak & 7 & 44 & 9 & 56 & & \\
\hline Kongenital & $\mathrm{Ya}$ & 4 & 36 & 7 & 64 & 1,000 & $0,79(0,21-2,95)$ \\
\hline & Tidak & 29 & 42 & 40 & 58 & & \\
\hline Tumor & $\mathrm{Ya}$ & 4 & 40 & 6 & 60 & 1,000 & $0,94(0,24-3,64)$ \\
\hline & Tidak & 29 & 41 & 41 & 59 & & \\
\hline Asfiksia & $\mathrm{Ya}$ & 0 & 0 & 4 & 100 & 0,139 & \\
\hline & Tidak & 33 & 43 & 43 & 57 & & \\
\hline Prematur & $\mathrm{Ya}$ & 2 & 25 & 6 & 75 & 0,459 & $0,44(0,83-2,34)$ \\
\hline & Tidak & 31 & 43 & 41 & 57 & & \\
\hline Perdarahan & $\mathrm{Ya}$ & 4 & 50 & 4 & 50 & 0,711 & $1,44(0,34-6,41)$ \\
\hline & Tidak & 29 & 40 & 43 & 60 & & \\
\hline CMV & $\mathrm{Ya}$ & 0 & 0 & 3 & 100 & 0,264 & \\
\hline & Tidak & 33 & 43 & 44 & 57 & & \\
\hline Meningitis & $\mathrm{Ya}$ & 1 & 50 & 1 & 50 & 1,000 & $1,44(0,87-23,84)$ \\
\hline & Tidak & 32 & 41 & 46 & 59 & & \\
\hline Ensefalitis & $\mathrm{Ya}$ & 5 & 56 & 4 & 44 & 0,477 & $1,92(0,47-7,77)$ \\
\hline & Tidak & 28 & 40 & 43 & 60 & & \\
\hline TB & $\mathrm{Ya}$ & 4 & 40 & 6 & 60 & 1,000 & $0,94(0,24-3,64)$ \\
\hline & Tidak & 29 & 41 & 41 & 59 & & \\
\hline Meningoensefalitis & $\mathrm{Ya}$ & 9 & 75 & 3 & 25 & 0,023 & $5,5(1,36-22,26)$ \\
\hline & Tidak & 24 & 35 & 44 & 65 & & \\
\hline Edema otak & $\mathrm{Ya}$ & 7 & 39 & 11 & 61 & 0,817 & $0,88(0,30-2,58)$ \\
\hline & Tidak & 26 & 42 & 36 & 58 & & \\
\hline Leukimia limfoblastik & $\mathrm{Ya}$ & 3 & 75 & 1 & 55 & 0,301 & $4,60(0,46-46,31)$ \\
\hline akut & Tidak & 30 & 39 & 46 & 61 & & \\
\hline Pneumonia & Ya & 7 & 54 & 6 & 46 & 0,313 & $1,84(0,56-6,08)$ \\
\hline & Tidak & 26 & 39 & 41 & 61 & & \\
\hline Abses otak & $\mathrm{Ya}$ & 0 & 0 & 2 & 100 & 0,509 & \\
\hline & Tidak & 33 & 42 & 45 & 58 & & \\
\hline Kista & $\mathrm{Ya}$ & 1 & 25 & 3 & 75 & 0,639 & $0,46(0,05-4,61)$ \\
\hline & Tidak & 32 & 42 & 44 & 58 & & \\
\hline Mielokel & Ya & 2 & 25 & 6 & 75 & 0,459 & $0,44(0,83-2,34)$ \\
\hline & Tidak & 31 & 43 & 41 & 57 & & \\
\hline OMK & $\mathrm{Ya}$ & 1 & 100 & 0 & 0 & 0,412 & \\
\hline & Tidak & 32 & 41 & 47 & 59 & & \\
\hline Total & & 33 & 41 & 47 & 59 & & \\
\hline
\end{tabular}


Denisa Dwi Rahmayani dkk: Profil klinis dan faktor risiko hidrosefalus komunikans dan non komunikans

Tabel 4. Analisis multivariat

\begin{tabular}{lccc}
\hline Variabel & Koefisien & $\mathrm{p}$ & OR (IK95\%) \\
\hline Myelocele & $-0,777$ & 0,403 & $0,46(0,07-2,84)$ \\
Jenis kelamin & $-0,589$ & 0,267 & $0,55(0,2-1,57)$ \\
Perdarahan & 1,211 & 0,144 & $3,36(0,66-17,03)$ \\
Edema otak & $-0,981$ & 0,171 & $0,37(0,09-1,53)$ \\
Ensefalitis & 0,968 & 0,011 & $6,32(1,53-26,03)$ \\
Meningoensefalitis & 1,705 & 0,017 & $5,5(1,36-22,26)$ \\
Konstanta & $-0,606$ & 0,017 & 0,54 \\
\hline
\end{tabular}

meningoensefalitis memiliki probabilitas $75 \%$ untuk menderita hidrosefalus komunikans.

\section{Pembahasan}

Secara distributif didapatkan laki-laki lebih banyak menderita hidrosefalus, baik tipe komunikans maupun non komunikans, dibandingkan perempuan dengan rasio 2,1:1. Hal tersebut hampir serupa dengan penelitian yang dilakukan Islam $\mathrm{dkk}^{9}$ yang melaporkan rasio 2,6:1 untuk kejadian hidrosefalus pada laki-laki. Abdullah dan Naing ${ }^{10}$ juga melaporkan rasio pasien hidrosefalus di Malaysia sebesar 3:1 untuk laki-laki. Status sosial-ekonomi merupakan salah satu faktor yang dirasa sebagai penyebab, hal ini dikarenakan masyarakat dengan kelas sosial yang lebih rendah lebih berhati-hati dalam menjaga bayi laki-laki dan relatif lebih lalai pada bayi perempuan. ${ }^{9}$ Dominasi laki-laki ini juga memiliki keterkaitan dengan faktor genetik, yaitu gen resesif terkait-X yang menyebabkan obstruksi akuaduktus sehingga terjadi hidrosefalus non komunikans. ${ }^{11}$

Penderita hidrosefalus terbanyak berada pada kategori infant, yaitu pasien dengan usia terbanyak antara 1-5 bulan. Studi populasi oleh Islam dkk ${ }^{9}$ pada bayi baru lahir hingga berumur 12 bulan menunjukkan bahwa umur 4-6 bulan merupakan umur terjadinya hidrosefalus paling banyak. Sementara itu, studi di Afrika dilaporkan bahwa usia 2-3 bulan merupakan usia puncak terjadinya hidrosefalus. ${ }^{12}$ Abdullah dan Naing ${ }^{10}$ melaporkan distribusi usia pasien hidrosefalus anak di Malaysia, yaitu 30\% neonate, 35\% berusia 1 bulan sampai 1 tahun, $28 \%$ berusia $1-5$ tahun dan 19 $6.7 \%$ berusia 6-13 tahun.

Tujuh puluh dua koma lima persen pasien hidrosefalus berasal dari luar Surabaya dan 53,75\% merupakan kasus rujukan. Van Landingham ${ }^{8}$ melaporkan bahwa distribusi geografis tidak memiliki pengaruh yang signifikan terhadap lokalisasi hidrosefalus.
Hidrosefalus tidak hanya menimbulkan gangguan neurologis seperti gangguan motorik, retardasi mental, atau penurunan intelegensi, tetapi juga gangguan urologi dan bowel. ${ }^{3}$ Pada penelitian ini didapatkan pasien hidrosefalus yang mengalami gizi kurang $17,5 \%$ dan gizi buruk 7,5\%.

Hasil penelitian menunjukkan bahwa tidak ada hubungan antara tipe hidrosefalus dengan edema otak, tetapi secara deskriptif menunjukkan bahwa manifestasi klinis hidrosefalus terbanyak adalah edema otak. Hal tersebut sesuai dengan penelitian Fishman ${ }^{13}$ yang melaporkan bahwa edema otak dapat terjadi pada berbagai bentuk hidrosefalus obstruktif/ non komunikans. Patofisologi edema otak pada hidrosefalus non komunikans dijelaskan Unterberg dkk ${ }^{14}$ dan Jha, ${ }^{15}$ yaitu edema interstisial yang menyebabkan obstruksi aliran keluar cairan serebrospinal dan tekanan intraventrikular yang meningkat. Hal tersebut diduga akibat protein integral pada membran sel otak yang disebut Aquaporin-4 (AQP4) yang mengatur pergerakan cair keluar masuk otak terganggu sehingga memperburuk terjadinya hidrosefalus obstruktif. ${ }^{16}$ Ketika terjadi pembengkakan otak, aliran keluar CSS akan terhambat sehingga menyebabkan akumulasi CSS di dalam ventrikel, keadaan ini disebut hidrosefalus.

Pada penelitian ini, pasien meningoensefalitis dengan hidrosefalus komunikans 11,25\% dan ditemukan adanya hubungan antara meningoensefalitis dengan hidrosefalus komunikans. Hasil studi observasional Pelegrin $\mathrm{dkk}^{17}$ melaporkan bahwa $14 \%$ pasien meningoensefalitis akibat Listeria monocytogenes mengalami hidrosefalus dan hasil analisis multivariat memperlihatkan adanya hubungan antara hidrosefalus dan penggunaan antibiotik empirik yang tidak sesuai sebagai faktor risiko kematian. Studi retrospektif dari Taiwan ${ }^{18}$ meneliti bahwa insiden kejadian hidrosefalus dengan bakterial meningitis (sebagian 
besar agen kausatifnya adalah Klebsiella pneumoniae dan Streptococcus viridans) sebesar 21\% dan semuanya termasuk tipe hidrosefalus komunikans. Sebuah review sistematik dari Edmond $\mathrm{dkk}^{19}$ menganalisis tingkat risiko hidrosefalus akibat meningitis bakteri pada pasien lebih dari 1 bulan sebesar 7,1\%.

Meningoensefalitis sebagian besar disebabkan oleh virus atau bakteri. Penyebab meningoensefalitis pada penelitian ini sebagian besar belum diketahui, tetapi diduga lebih banyak akibat virus karena hasil kultur yang menunjukkan nilai negatif. Infeksi virus merupakan etiologi tersering dari meningitis aseptik. ${ }^{20}$ Patogen virus tersering yang menyebabkan infeksi SSP adalah HEV (human enterovirus), HSV-1, HSV-2, CMV, VZV, EBV. ${ }^{21}$ Data statistik dari studi terbaru menunjukkan bahwa hingga 57\% infeksi virus SSP akibat enterovirus, dan sebagian besar terjadi pada anak, ${ }^{22}$ kemudian diikuti oleh herpesvirus. ${ }^{20}$

Patofisiologi meningoensefalitis virus dijelaskan oleh Hartley, Evans, dan MacDermott. ${ }^{22}$ Virus pertama kali masuk ke tubuh melalui sistem respirasi, gastrointestinal, traktus urogenital atau melalui kulit. Sebagian besar virus bereplikasi dekat portal masuk dan memperoleh akses ke SSP melalui rute hematogen, kemudian masuk menyebrang ke pleksus koroid. Patogenesis terjadinya hidrosefalus komunikans adalah produksi yang berlebihan pada CSS atau absorpsi yang kurang di ruang subaraknoid. Virus yang telah mencapai pleksus koroid akan menyebar melalui CSS hingga mencapai meningeal dan sel ependim. Virus akan bereplikasi yang selanjutnya menyebabkan destruksi sel dan inflamasi. Respon inflamasi inilah yang menunjukkan simptom demam, kaku kuduk, sakit kepala dan fotofobia. Respon inflamasi ini juga membatasi replikasi virus dan lama sindrom meningitis. Inflamasi di dalam ruang CSS menyebabkan hambatan ambilan CSS oleh vili araknoid sehingga terjadi hidrosefalus komunikans. ${ }^{23}$

\section{Kesimpulan}

Angka kejadian hidrosefalus komunikans dan non komunikans pada anak di RSUD dr. Soetomo dari Januari 2014 hingga Januari 2016 sebesar 35,9\% dan $51,1 \%$. Edema otak merupakan manifestasi klinis terbanyak pada penderita hidrosefalus anak di RSUD Dr. Soetomo. Meningoensefalitis merupakan faktor risiko terjadinya hidrosefalus komunikans.

\section{Daftar pustaka}

1. Tully HM, Dobyns WB. Infantile hydrocephalus: a review of epidemiology, classification and causes. Eur J Med Gen 2014;57:359-68.

2. Cavalcanti DP, Salomão MA. Incidence of congenital hydrocephalus and the role of the prenatal diagnosis. Jornal de Pediatria 2003;79:135-40.

3. Persson, EK, Hagberg, G, Uvebrant, P. Hydrocephalus prevalence and outcome in a population-based cohort of children born in 1989-1998. Acta Paediatrica 2005;94:72632.

4. Maliawan S, Andi Asadul I, Bakta M. Perbandingan teknik endoscopic third ventriculostomy (ETV) dengan ventriculoperitoneal shunting (VP Shunting) pada hydrocephalus obtruktif: perbaikan klinis dan perubahan Interleukin- $\beta$, Interleukin-6, dan neural growth faktor cairan serebrospinalis [disertasi]. Denpasar: Universitas Udayana, 2008.

5. McAllister JP, Williams MA, Walker ML, Kestle JR, dkk. An update on research priorities in hydrocephalus: overview of the third National Institutes of Health-sponsored symposium "opportunities for hydrocephalus research: pathways to better outcomes". J Neurosurg 2015;123:1427-38.

6. Kumar V, Cotran RS, Robbins SL. Buku ajar patologi. Edisi ke-7. Jakarta: Penerbit. Buku Kedokteran EGC; 2007.h.346.

7. Zhang J, Williams MA, Rigamonti D. Genetics of human hydrocephalus. J Neurol 2007;253:1255-66.

8. Van Landingham M, Nguyen TV, Roberts A, Parent AD, Zhang J. Risk factors of congenital hydrocephalus: a 10 year retrospective study. J Neurol Neurosurg \& Psychiatry 2009;80:213-7.

9. Islam, MA, Amin, MR, Rahman, MA, Hossain, MA, Barua, KK, Hossain, M. Fontanelle as an indicator of hydrocephalus in early childhood. Bangladesh J Neurosci 2014;27:83-6.

10. Abdullah J, Naing NN. Hydrocephalic children presenting to a Malaysian community-based university hospital over an 8-year period. Pediatric Neurosurg 2001;34:13-9.

11. Ekici, AB, Hilfinger D, Jatzwauk M, Thiel CT, Wenzel D, Lorenz I, dkk. Disturbed WNT signalling due to a mutation in CCDC88C causes an autosomal recessive non-syndromic hydrocephalus with medial diverticulum. Mol Syndromol 2010;1:99-112.

12. Salvador SF, Henriques JC, Munguambe M, Vaz RM, Barros HP. Hydrocephalus in children less than 1 year of age in Northern Mozambique. Surgl Neurol Int 2014;5:175. doi: 10.4103/2152-7806.146489. eCollection 2014.

13. Fishman, RA. Steroids in the treatment of brain edema. NEJM 1982;306:359-60. 
14. Unterberg, AW, Stover J, Kress B, Kiening KL. Edema and brain trauma. Neuroscience 2004;129:1019-27.

15. Jha, SK. Cerebral edema and its management. Med J Armed Forces India (MJAFI) 2003;59:326-31.

16. Papadopoulos MC, Verkman AS. Aquaporin-4 and brain edema. Pediatric Nephrol 2007; 22:778-84.

17. Pelegrín I, Moragas M, Suárez C, Ribera A, Verdaguer $\mathrm{R}$, Martínez-Yelamos S, dkk. Listeria monocytogenes meningoencephalitis in adults: analysis of factors related to unfavourable outcome. Infection 2014;42:817-27.

18. Wang KW, Chang WN, Chang HW, Wang HC, Lu CH. Clinical relevance of hydrocephalus in bacterial meningitis in adults. Surg Neurol 2005;64:61-5.

19. Edmond K, Clark A, Korczak VS, Sanderson C, Griffiths UK, Rudan I. Global and regional risk of disabling sequelae from bacterial meningitis: a systematic review and meta-analysis.
Lancet Infect Dis 2010;10:317-28.

20. Hoyer C, Eisele P, Ebert AD, Schneider S, Gass A, Fatar $\mathrm{M}$, dkk. Blood-CSF-barrier dysfunction is a marker for encephalitic involvement in patients with aseptic meningitis/ meningoencephalitis. J Clin Virol 2016;84:82-6.

21. Shi X, Wu R, Shi M, Zhou L, Wu M, Yang Y, dkk. Simultaneous detection of 13 viruses involved in meningoencephalitis using a newly developed multiplex PCR Mag-array system. Int J Infect Dis 2016;49:80-6.

22. Hartley L, Evans J, MacDermott NE. Management and outcome in viral meningo-encephalitis. Paediatrics and Child Health 2011;21:488-94.

23. Guney F, Gumus H, Ogmegul A, Kandemir B, Emlik D, Arslan U, Tuncer I. First case report of neurobrucellosis associated with hydrocephalus. Clin Neurol Neurosurg 2008;110:739-42. 